\title{
ZBTB16/RARA Fusion Protein
}

National Cancer Institute

\section{Source}

National Cancer Institute. ZBTB16/RARA Fusion Protein. NCI Thesaurus. Code C18292.

A fusion protein encoded by the ZBTB16/RARA fusion gene. This protein is comprised of the $\mathrm{N}$-terminal POZ domain and two of the nine zinc fingers of zinc finger and BTB domain-containing protein 16 fused to the C-terminal DNA and ligand binding domains of the retinoic acid receptor alpha protein. 